\title{
Oleoresin yield and carbon stocks in tapped subtropical Pinus elliottii forests
}

\author{
Kelly Cristine da Silva Rodrigues-Corrêa ${ }^{1}$, Tanise Luisa Sausen², Fernando S Rocha ${ }^{1}$, Arthur Germano Fett-Neto ${ }^{3^{*}}$ \\ From IUFRO Tree Biotechnology Conference 2011: From Genomes to Integration and Delivery \\ Arraial d'Ajuda, Bahia, Brazil. 26 June - 2 July 2011
}

\begin{abstract}
Background
Low-cost methods to mitigate the increasing levels of carbon dioxide in the atmosphere and their implications on global climate change have received considerable attention in the last years [1,2]. Afforestation is an important alternative to reduce the rise in atmospheric $\mathrm{CO}_{2}$ concentration due to the system's ability to fix carbon in forest biomass and soil [3]. Several studies have been performed to estimate carbon sequestration in temperate, tropical, and mediterranean forests ecosystems $[4,5]$. However, there are no reports related to carbon balance in pine forests used for oleoresin tapping grown under subtropical climate. The main goal of this research is to estimate the effect of resin tapping on $\mathrm{C}$ sequestration by Pinus elliottii forests.
\end{abstract}

\section{Material and methods}

\section{Resin tapping operation}

In June 2009, 90 slash pine (Pinus elliottii Engelm.) trees of a 14 year-old forest were selected based on a previously determined DBH interval (between $23.48 \pm 1.12$ and $22.77 \pm 0.88$ ). Since the beginning of the essay, pine trees have been biweekly stimulated to produce oleoresin [6]. Three treatments were evaluated for pine biomass increase and oleoresin yield: bark streak (mechanical wound), paste (mechanical wound + chemical stimulation) and control (intact trees). At the end of each season, the released oleoresin was collected and weighed in a digital balance. The results shown below were obtained between Spring 2009 and Winter 2010.

\footnotetext{
* Correspondence: fettneto@cbiot.ufrgs.br

${ }^{3}$ Department of Botany and Center for Biotechnology, Federal University of Rio Grande do Sul, P.O. Box 15005, 91501-970 Porto Alegre, RS, Brazil

Full list of author information is available at the end of the article
}

Biomass production and carbon accumulation

In November 2010, fifteen pine trees (5 intact tree control, 5 mechanically wounded, and 5 paste stimulated tapped trees) were felled and weighed in the field to estimate the above and belowground total fresh biomass of trees. Sub-samples of each part of trees were collected and dried in an oven at $105^{\circ} \mathrm{C}$ until reaching constant dry weight. The carbon content per unit dry weight present in the aboveground and belowground biomass was estimated using a carbon content of $50 \%$ [7]. Data were analyzed for differences between resin treatments (bark streak vs. paste) by comparison of means by ANOVA and Tukey test (Systat Software Inc., Richmond, CA USA); significance was set at $\mathrm{P} £ 0.05$ ).

\section{Results and conclusions}

The seasonal oleoresin production did not show the same pattern previously observed [8]. The highest oleoresin yield was observed in Spring (data not shown). Statistical differences between oleoresin yields of pastetreated and control (bark streak) trees were observed (Figure 1). These results are in agreement with the fact that besides genetic traits, physiological status, season and environmental conditions [9-11], inducible oleoresin biosynthesis consistently responds to exogenous chemical stimuli $[6,8]$.

The production of aboveground biomass expressed on a dry weight basis was significantly higher than that of belowground biomass. This was observed for all treatments, and no significant differences were detected in biomass production and partition for tapped (both plain wound and chemical stimulation) or control trees (Figure 2). The aboveground biomass showed a carbon accumulation between 221.3 and $235.9 \mathrm{Mg} \mathrm{C} \mathrm{ha}^{-1}$ and in the roots, the carbon accumulation is in the range between 35.7 and $48.3 \mathrm{MgC} \mathrm{ha}^{-1}$. 


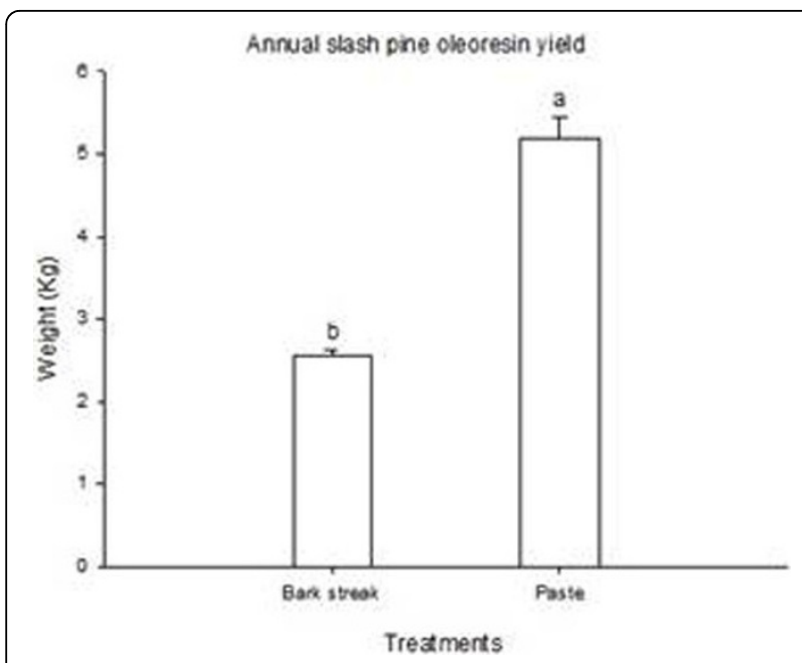

Figure 1 Annual production of oleoresin by pine trees. Standard errors of the means are indicated on top of bars. Bars with different letters indicate significant difference by a Tukey test $(P \leq 0.05)$. Each mean was calculated with 30 individual trees.

These results indicate that carbon stored in aboveground biomass appeared to represent the main carbon pool of tree biomass and that resin tapping had minor impact on $\mathrm{C}$ allocation in wood biomass, considering the time frame and stand age examined. Further studies and sampling times are ongoing in order to better characterize carbon stocks in subtropical slash pine plantations and to elucidate the contribution of oleoresin production in carbon stocks and its relation with $\mathrm{C}$ in wood biomass.

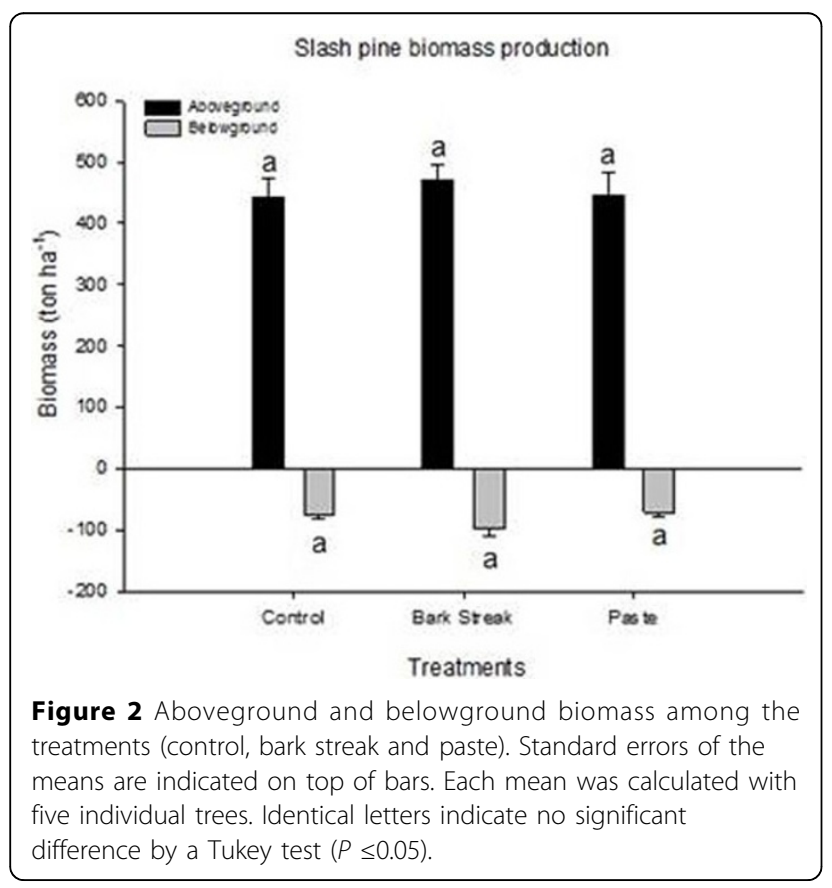

\section{Acknowledgements}

Funding for this investigation was provided by a consortium of forest companies (Trevo Florestal, Irani/Habitasul Florestal, Florestal Palmares) and the Brazilian agencies National Council for Scientific and Technological Development (CNPq), National Committee for Improvement of Higher Level Education Personnel (CAPES) and Rio Grande do Sul State Foundation for Research Support (Fapergs).

\section{Author details}

'Departament of Botany, Federal University of Rio Grande do Sul, Porto Alegre, RS, Brazil. ${ }^{2}$ Center for Biotechnology, Federal University of Rio Grande do Sul, P.O. Box 15005, 91501-970 Porto Alegre, RS, Brazil. ${ }^{3}$ Department of Botany and Center for Biotechnology, Federal University of Rio Grande do Sul, P.O. Box 15005, 91501-970 Porto Alegre, RS, Brazil.

Published: 13 September 2011

\section{References}

1. Montagnini F, Nair PKR: Carbon Sequestration: An under exploited environmental benefit of agroforestry systems. Agroforestry Systems 2004, 61:281-295.

2. Winner WE, Thomas SC, Berry JA, Bond BJ, Cooper CE, Hinckley TM, Ehleringer JR, Fessenden JE, Lamb B, McCarthy S, McDowell NG, Phillips N, Williams M: Canopy Carbon Gain and Water Use Analysis of Old-growth Conifers in the Pacific Northwest. Ecosystems 2004, 7:482-497.

3. Climate Change: The Physical Science Basis. Contribution of Working Group I to the Fourth Assesssment Report of the Intergovernmental Panel on Climate Change. UNEP, New York; 2007.

4. Návar J: Allometric equations for tree species and carbon stocks for forests of northwestern México. Foret Ecology and Management 2009, 257(2):427-434.

5. Redondo-Brenes A: Growth, carbon sequestration, and management of native tree plantations in humid regions of Costa Rica. New Forests 2007, 34:253-268.

6. Rodrigues KCS, Azevedo PCN, Sobreiro LE, Pelissari P, Fett-Neto AG: Oleoresin yield of Pinus elliottii plantations in a subtropical climate: effect of tree diameter, wound shape and concentration of active adjuvants in resin stimulating paste. Industrial Crops and Products 2008, 27:322-327.

7. Pettersen RC: The chemical composition of wood. In The Chemistry of Wood. Advances in Chemistry Series 207, American Chemical Society, Washington, DC, USA;Rowel, R.M. 1984:57-126.

8. Rodrigues KCS, Fett-Neto AG: Oleoresin yield of Pinus elliottii in a subtropical climate: Seasonal variation and effect of auxin and salicylic acid-based stimulant paste:. Industrial Crops and Products 2009, 30(2):316-320.

9. Steele CL, Lewinsohn E, Croteau R: Induced oleoresin biosynthesis in grand fir as a defense against bark beetles: (monoterpenes/turpentine/ diterpenoid resin acids/rosin/stress effects). In Proc. Natl. Acad. Sci. Volume 92. USA; 1995:4164-4168.

10. Lewinsohn E, Gijzen M, Muzika RM, Barton K, Croteau R: Oleoresinosis in Grand Fir (Abies Grandis) saplings and mature trees 1: modulation of this wound response by light and water stresses. Plant Physiology 1993, 101:1021-1028.

11. Roberds JH, Strom BL, Hain FP, Gwaze DP, McKeand SE, Lott LH: Estimates of genetic parameters for oleoresin and growth traits in juvenile loblolly pine. Canadian Journal of Forest Research 2003, 33:2469-2476.

doi:10.1186/1753-6561-5-S7-P100

Cite this article as: Rodrigues-Corrêa et al:: Oleoresin yield and carbon stocks in tapped subtropical Pinus elliottii forests. BMC Proceedings 2011 5(Suppl 7):P100. 